J. Kyushu Dent. Soc. 53 ( 2 ):318 324, 1999.

\title{
Analysis of Reconstruction of Mandibular Defects Using Autogenous Bone Graft and/or Metallic Reconstruction Plate
}

\author{
Hideo Kurokawa, Yoshihiro Yamashita, Maki Yamashita \\ and Minoru Kajiyama
}

\author{
Second Department of Oral Surgery (Chief : Prof. Minoru Kajiyama) \\ Kyushu Dental College, Kitakyushu, Japan
}

Key words : Mandibular reconstruction/Bone graft/Metallic plate/Masticatory function

Accepted on February 25, 1999

Mandibular reconstruction is important for providing good functional and cosmetic results after resection of the mandible. Mandibular reconstruction following excision of the mandible has been conventionally achieved by free bone grafting using autogenous bone, such as ilium or rib $^{1)}$. With the recent development of metallic plates for stabilization of the mandible, mandibular reconstruction with a combination of a metallic plate and a pedicled osteomyocutaneous flap or revascularized osteomyocutaneous flaps has been described for repairing defects following extensive segmental resection, unilateral resection, or hemiresection of the mandible ${ }^{2-4}$. Although mandibular contour can be reestablished by these methods, they do not always produce satisfactory results in the restoration of occlusion and masticatory function.

This report describes our experience using various reconstruction procedures and the functional outcome is analyzed, with attention to associated early and late complication.

\section{Patients and Methods}

Reconstruction of mandibular defects was performed on 69 patients in our department during the 16 years from 1981 to 1996 . The patient's ages ranged from 19 years to 72 years (mean, 53.3 years). The sex was 32 males to 37 females. Of the 69 cases, 43 were oral malignant tumors, sixteen were oral benign tumors, seven were odontogenic cysts and three were chronic osteomyelitis (Table 1). The extent of mandibular resection in the 69 cases is shown in Fig. 1. There were immediate reconstruction on 55 cases and secondary reconstruction on 14 cases.

The amount of bone required was outlined and then cut using a tungsten carbide fissure bur or a high speed oscillating saw. The metallic plates of appropriate size were chosen based on preoperative cephalometric radiographs made in the posteroanterior, lateral, and occipitomental directions. The plates were bent to the predicted curvature of the angle or mentum using a model or paper template as a guide. The adaptability was improved by repeated adjustment during operation. Holes in the mandibular stumps were made using a 
Table 1 Histopathological diagnosis of 69 patients with mandibular reconstructions

\begin{tabular}{|c|c|c|c|}
\hline \multicolumn{2}{|c|}{ Diagnosis } & \multicolumn{2}{|l|}{ Case } \\
\hline \multirow[t]{8}{*}{ Malignant tumor } & Squamous cell carcinoma & & 35 \\
\hline & Gingival cancer & 29 & \\
\hline & Oral floor/Tongue cancer & 5 & \\
\hline & Buccal mucosa-cancer & 1 & \\
\hline & Osteogenic sarcoma & & 4 \\
\hline & Fibro-sarcoma & & 3 \\
\hline & & & 1 \\
\hline & & Total & 43 \\
\hline \multirow[t]{3}{*}{ Benign tumor } & Ameloblastoma & & 15 \\
\hline & Ossifying fibroma & & 1 \\
\hline & & Total & 16 \\
\hline \multirow[t]{3}{*}{ Odontogenic cyst } & Odontogenic keratocyst & & 6 \\
\hline & Follicular cyst & & 1 \\
\hline & & Total & 7 \\
\hline \multirow[t]{3}{*}{ Others } & Osteomyelitis & & 2 \\
\hline & Others & & 1 \\
\hline & & Total & 3 \\
\hline
\end{tabular}
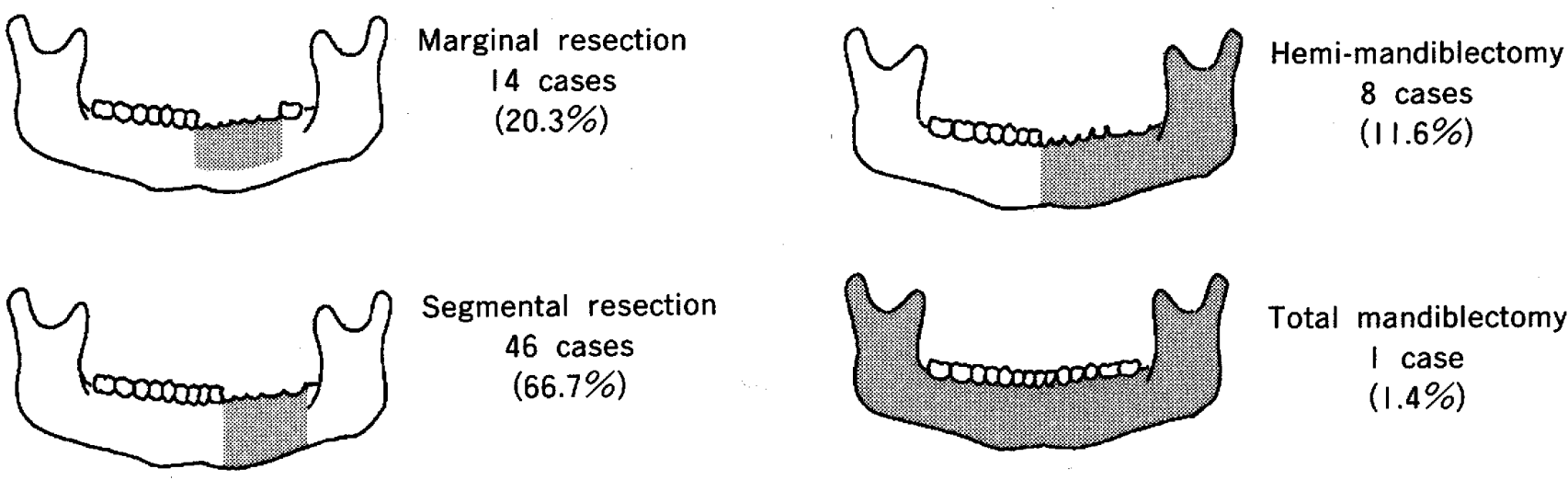

Segmental resection 46 cases $(66.7 \%)$

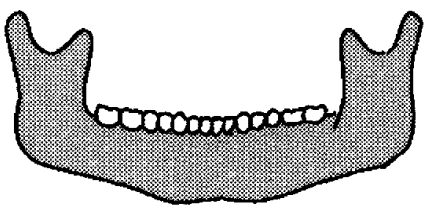

Total mandiblectomy

1 case

$(1.4 \%)$

Fig. 1 Type of mandibular defects.

drill and tap, and the plate was fixed with two or three screws on each end. Ten of 69 cases required a myocutaneous flap to close soft tissue defects : four patients had pectoralis major myocutaneous flaps, three had deltopectoral flaps and three had cervical island skin flaps.

To determine masticatory function, follow-up interviews were perfomed with 26 patients underwent immediate mandibular reconstruction after segmental mandibular resection or hemimandiblectomy, by Yamamoto's chart of masticatory efficiency ${ }^{5}$.

\section{Results}

Following mandibular resection, the mandibular reconstruction with an autogenous bone 


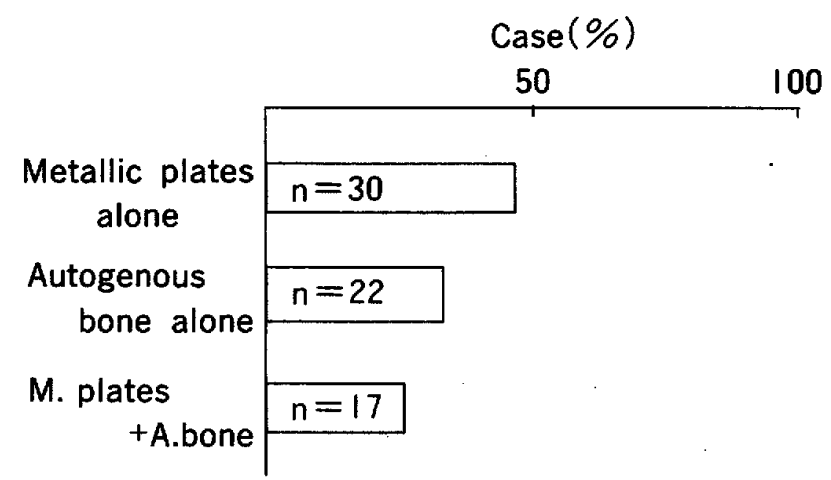

Fig. 2 Methods of mandibular reconstruction.

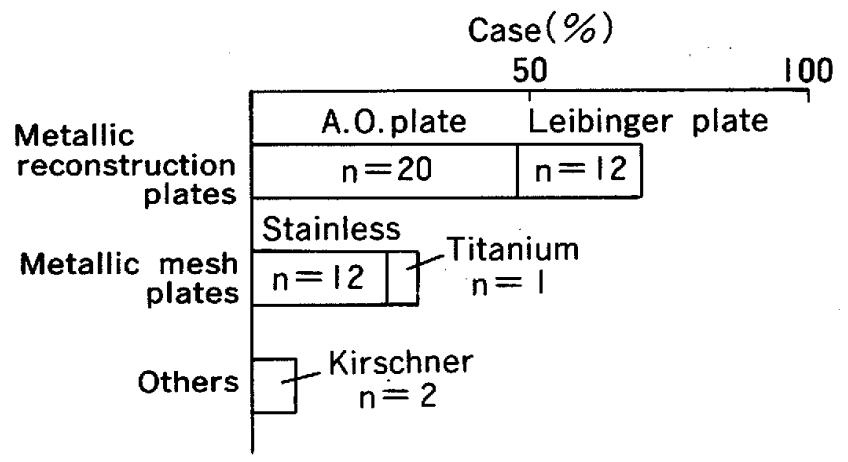

Fig. 4 Method of mandibular reconstruction with metallic plates and/or bone grafts.

Table 2 Prognosis after mandibular reconstruction using metallic plates and/or bone grafts

\begin{tabular}{l|rr}
\hline \hline \multicolumn{1}{c|}{ Complications } & Cases & \multicolumn{1}{c}{$\%$} \\
\hline Inflammatory complication & $9 / 69$ & 13.0 \\
Chronic perforation & $2 / 47$ & 4.3 \\
Removal of metallic plates & $6 / 69$ & 8.7 \\
$\quad$ and/or bone & & \\
\hline
\end{tabular}

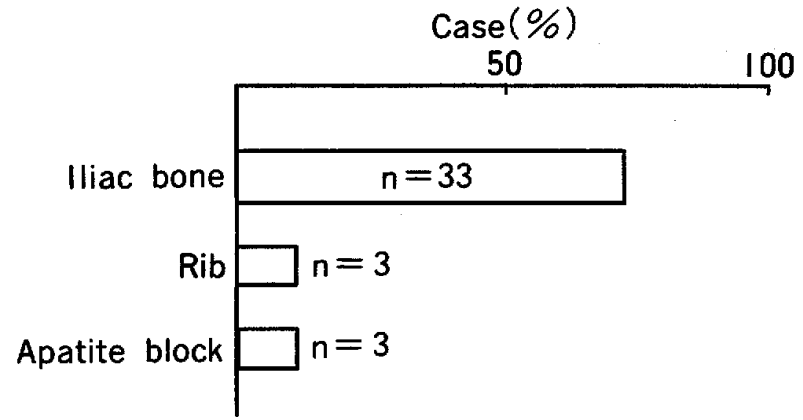

Fig. 3 Method of mandibular reconstruction with bone grafts.

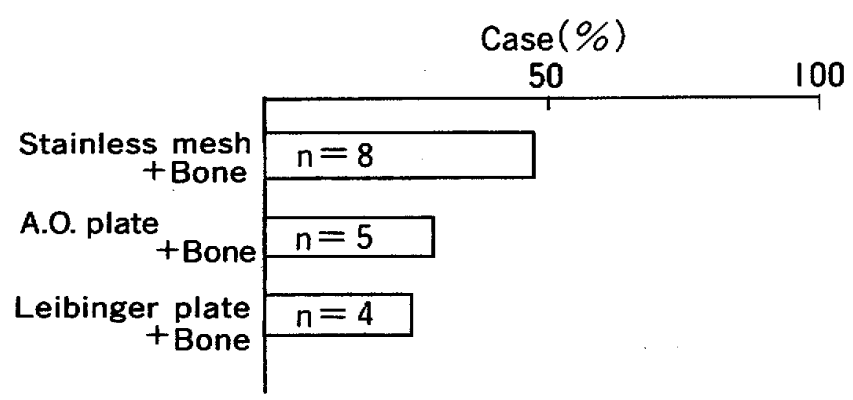

Fig. 5 Method of mandibular reconstruction with metallic plates and/or bone grafts.

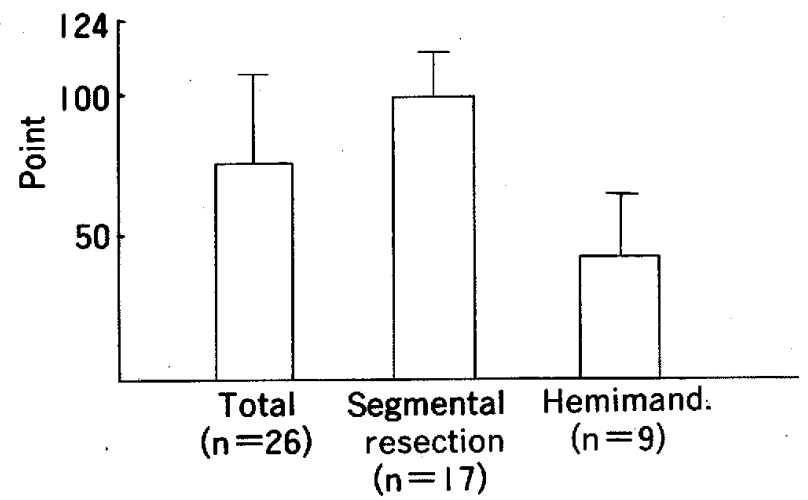

Fig. 6 Masticatory efficiency for patient with mandibular resection by Yamamoto's chart. 
graft and/or a metallic plate was carried out in 69 patients : 30 patients were reconstructed with only a metallic plate for stabilization of the mandible, 22 patients with only an autogenous bone graft, and 17 patients with a combination of a metallic palte and an autogenous bone graft. An autogenous bone graft was used in 39 patients after mandibular resection (Fig. 2). Thirty three patients were reconstructed with an iliac crest bone graft, three patients with a rib segment, and three patients with a hydroxyapatite block (Fig. 3). The grafted bone was fixed to the stumps with stainless steel wires or miniplates. A metallic plate was used in 47 patients after mandibular resection. Thirty two patients were reconstructed with an $\mathrm{AO}$ or Leibinger reconstruction plate, thirteen patients with a stainless steel or titanium mesh tray, and two patients with a Kirschner wire. Moreover, in seventeen patients who were reconstructed with a combination of a metallic palte and an autogenous bone graft, a stainless steel mesh tray was used in eight patients, an AO reconstruction plate in five patients, and a Leibinger reconstruction plate in four patients (Fig. 4, 5).

There were complications in 11 cases (15.9\%), and these are summarized in Table 2. They can be divided into inflammations, dehiscence and infection at the plate site, and noninflammations due to mechanical stress in the plate or the grafted bone. Relating the inflammatory complications to the localization of the plate or the grafted bone showed the lowest rate after reconstruction of the mandibular body. Reconstruction of the ramus gave the most complications. The plate exposures occurred in two cases with a relatively large resection of the mandible including the mandibular angle or the ramus. There were 5 cases of infection near the plate or the grafted bone. However, These cases were successfully treated with local care without extraoral plate exposure. Five of the 11 complications were successfully treated without plate or grafted bone removal.

The masticatory function after mandibular reconstruction in 26 cases with segmental resection of the mandible or hemimandiblectomy is shown in Fig. 6 . In 21 of 26 patients (80.8\%), a denture was used. The mean point of the masticatory function after mandibular reconstruction in 9 patients with hemimandiblectomy was $42.7 \pm 18.9$ point, which was significantly lower than the $94.4 \pm 12.9$ point in 17 patients with segmental resection of the mandible.

\section{Discussion}

Several methods of reconstruction have been used, with varying degrees of success. These include extraskeletal (external) fixation, steel or titanium mesh, nonvascularized bone grafts, Kirschner wire, darcon mesh, autogenous frozen mandible, osteomyocutaneous flap, titaniumcoated hollow-screw reconstruction plates (THRP), cancellous bone, and rigid fixation with metallic plates ${ }^{6-8}$. The main goals of reconstructive efforts are to improve function, form, and quality of life while minimizing serious risk to the patient ${ }^{1)}$.

Although the ideal mandibular replacement has yet to be discovered, qualities of such a prosthesis would permit 1 ) easy application with minimal additional operating room time, 2 ) provision of a solid arch with which the maxilla can articulate, 3 ) no compromise of 
cancer curability, 4) closure of soft tissue defects and bone gaps, 5 ) minimal cosmetic deformity, and 6) satisfactory function ${ }^{1,9,10)}$. Moreover, the choice depends on the histologic diagnosis of the tumor and the location and extent of the mandibular defect ${ }^{1)}$. In our department, metallic reconstruction plates have been used for immediate mandibular reconstruction in malignant tumor cases, and iliac bone or alumina ceramics have been used for permanent reconstruction of benign tumors ${ }^{12}$. The advantages of the metallic plate are as follows: 1 ) it can be easily shaped and adapted to any type of mandibular defect, 2 ) it is really available and economical, and 3 ) it has sufficiant structual rigidty to maintain the mandibular fragment in proper position and the teeth in the proper occlusion ${ }^{11,12)}$.

After mandibular reconstruction, most patients complained of various abnormalities of mandibular movement, sensory discomefort of the flap in the oral cavity, and a feeling of unadaptability of the prosthesis owing to changes in the supporting tissues of the mandible ${ }^{13,14)}$. In our cases, there was no relationship between plate exposure and reconstruction with a mucocutaneous flap. Therefore, the cause was considered to depend on the condition of the lining skin over the plate or the shape of the plate. The shape of the plate should be planned to avoid excessive pressure on the soft tissues surrounding $\mathrm{it}^{15)}$. We have found that preparation of a plate smaller than the actual size of the mandible and placemant of the plate on the medial side, together with contour adjustment of the plate and manipulation during the operation, help to prevent plate exposure. Moreover, in immediate reconstruction of the posterior region of the mandible following segmental resection, our use of a metallic plate or a myocutaneous flap and bone graft produced a relatively favorable postoperative course, as did delayed reconstruction using an autogenous iliac bone or rib segment. We therefore believe that delayed bone grafting after immediate fixation using a metallic plate to bridge the mandibular defect may be a safer procedure.

Restoration of mandibular continuity is the major purpose of reconstruction with a metallic plate and/or substitute bone material. Restoration of mastication using a prosthesis in such situations is difficult ${ }^{14,15)}$. In patients having teeth on the unaffected side, this method of repair, though not adequate to achieve perfect restoration of mastication, is relatively satisfactory ${ }^{14}$. In edentulous patients, restoration of the masticatory function is very difficult. Autogeneous bone grafts are more usefull than bone substitutes in supporting a prosthesis ${ }^{14)}$. In our cases, 21 of the 26 patients $(80.8 \%$ ) have good mandibular function. Therefore, these reconstruction was helpfull restring masticatory function.

\section{Conclusion}

The functional outcome of 69 patients who had mandibular resection and were reconstructed with a metallic plate and/or a bone graft was retrospectively analyzed. There were complications in 11 cases $(15.9 \%)$ : postoperative inflammation or infection occurred 9 times, plate exposure twice. Six cases of the plate and/or the grafted bone had to be removed prematurely due to the complication. A prosthesis was used more frequently by patients when reconstruction was performed using a metallic and a bone graft. These 
reconstruction was helpfull for restoring mandibular contour and masticatory function. Improved mandibular function and esthetics may allow future patients to be offered easily reconstruction routinely.

\section{Reference}

1) Papazian, M. R., Castillo, M. H., Campbell, J. H. and Dalrymple, D.: Analysis of reconstruction for anterior mandibular defects using AO plates. J. Oral Maxillofac. Surg. 49 : 1055-1059, 1991.

2) Kobayakawa, T., Kudo, K. and Ishikawa, Y.: Clinical course and evaluation after the use of A-O plate for defects following the mandibular resection. Jpn. J. Oral Maxillofac. Surg. 33: 1651-1657, 1987.

3) Vuillemin, T. and Sutter, F.: Mandibular reconstruction with the THOP condylar prothesis after hemimandibulectomy. J. Craniomaxillofac. Surg. 17: 78-81, 1989.

4) Murphy, J. B., Weisman, R. A. and Kent, K.: The use of stabilization plates in the immediate repair of defects following mandibular resection. Oral Surg. 68:380-382, 1989.

5) Yamamoto, T.: Posterior artificial teeth arrangement. Part 2 Reversed occlusion. J. Pract. Prosth. 5 : 395-400, 1972.

6) Kruger, E. and Krumholz, K.: Results of bone grafting after rigid fixation. J. Oral Maxillofac. Surg. 42 : 491-494, 1984.

7 ) Chow, J. M. and Hill, J. H.: Primary mandibular reconstruction using the A $-\mathrm{O}$ reconstruction plate. Laryngoscope 46: 768-770, 1986.

8 ) Komisar, A., Warman, S. and Danziger, E.: A critical anlysis of immediate and delayed reconstruction using A-O plates. Arch. Otolaryngol. Head Neck Surg. 115: 830-833, 1989.

9) Piggot, J. A. and Logan, A. M.: Mandibular reconstruction by simple bone graft. Br. J. Plast. Surg. $36: 9-14,1983$.

10) Leipzig, B. and Cummings, C. W.: The current status of mandibular reconstruction using autogenous frozen mandibular grafts. Head Neck Surg. 6: 992-994, 1984.

11) Ueyama, Y., Naitoh, R., Yamagata, A. and Matsumura, T.: Analysis of reconstruction of mandibular defects using single stainless steel $A-O$ reconstruction plates. J. Oral Maxillofac. Surg. $54: 858-862,1996$.

12) Schusterman, M. A., Reece, G. P., Kroll, S. S. and Weldon, M. E.: Use of the AO plate for immediate mandibular reconstruction in cancer patients. Plast. Reconstr. Surg. 88: 588-592, 1991.

13) Freitag, V., Hell, B. and Fischer, H.: Experience with AO reconstruction plates after partial mandibular reconstruction involving its continuity. J. Craniomaxillofac. Surg. 19: 191-198, 1991.

14) Kudo, K., Shoji, M., Yokota, M. and Fujioka, Y.: Evaluation of mandibular reconstruction techniques following resection of malignant tumors in the oral region. J. Oral Maxillofac. Surg. 50: $14-21,1992$.

15) Vaughan, E. D. and Barnard N. A.: Osteosynthetic titanium mini-plate fixation of composite radial forearm flaps in mandibular reconstruction. J. Craniomaxillofac. Surg. 19: 243-248, 1991. 


\title{
再建用金属プレートおよび自家骨を用いた 下顎欠損の再建についての検討
}

\author{
黒 川 英 雄 - 山 下 善 弘 - 山下 真 紀 \\ 梶山稔 \\ 九州歯科大学口腔外科学第 2 講座 (主任 : 梶山 稔教授)
}

平成 11 年 2 月 25 日

私たちは，下㖽骨切除を行い金属プレートおよび骨移 植による下顎骨再建を施行した 69 症例について, その 機能的評価を検討した． 合併症は 11 例 (15.9\%) に認 められた。 その内訳は, 手術後の炎症あるいは感染が 9
例, プレートの露出が 2 例であった. そのうち, 6 例はプ レートあるいは移植骨を除去した．補経物は下靧骨再建 後によく使用されていた。 また，今回の下顎骨再建では 下額豊隆や咀哷機能の回復に有用であった。 